\title{
CMAJ 2011 election survey: health human resources
}

$\mathrm{E}$ asily the most breathtaking proposal for health human resources advanced over the past decade was a comprehensive "pan-Canadian" strategy for educating, recruiting, licensing and equipping doctors that was recommended by a blue-ribbon panel called Task Force Two in 2006.

The comprehensive plan, A Physician Human Resource Strategy for Canada: Final Report, urged wholesale reforms in five areas related to physician supply - education and training; interprofessionalism; recruitment and retention; licensure, regulatory issues and liability; and, infrastructure and technology - while proposing that responsibility for overhauling the current system be vested with some manner of national agency (www.cmaj.ca /cgi/doi/10.1503/cmaj.060598).

The proposal, though, was eventually consigned to gather dust on library shelves after it became mired in quintessential Canadian squabbles over jurisdiction. Various medical associations argued that they shouldn't have to relinquish their licensing authority, while several provinces objected to a national approach to health human resources on the grounds that it would limit their ability to recruit doctors to underserviced areas.

Small wonder, then, that no political party boldly stepped out during CMAJ's 2011 election survey by advocating policies that favour some sort of pan-Canadian approach to educating, recruiting and licensing doctors and other health professionals.

The New Democrats come closest to such a notion, with a series of promises including one to "establish a Health Human Resources Centre, often referred to as an Observatory, to identify the need for health human resources across the country and help plan for the future."

The party would also forgive all student loans to all medical students who agree to family practice for a 10 -year

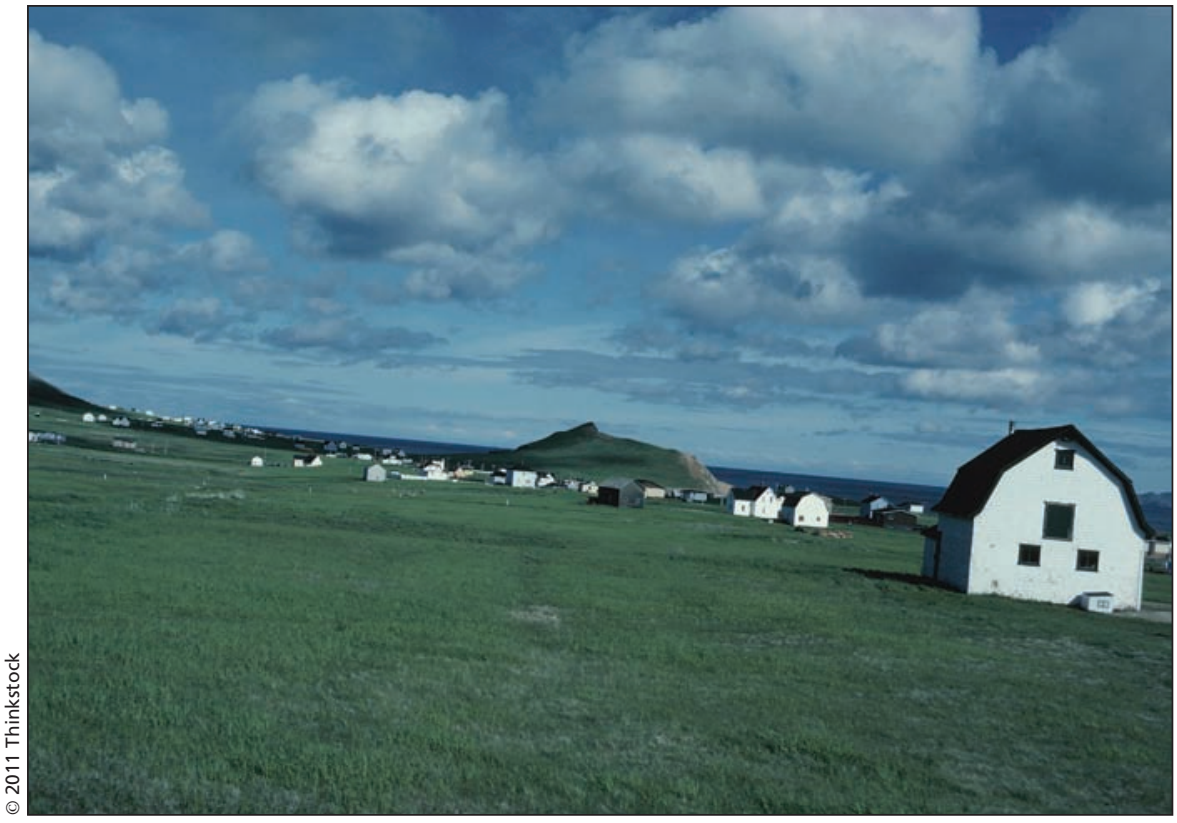

Election promises from Canada's political parties regarding health human resources are largely confined to relatively modest measures aimed at recruiting young doctors to underserviced areas.

period and spend $\$ 80$ million to train an additional 1200 physicians over 10 years, 6000 nurses over 6 years and an unspecified number of other health professionals. As well, they would "establish programs aimed at recruiting and supporting low-income, rural and aboriginal medical students," create a fund to repatriate 300 Canadian physicians within four years, and revise the foreign credential recognition system to make it easier for physicians educated abroad to work in Canada.

The prescriptions of the remaining political parties were largely confined to relatively modest measures aimed at recruiting young doctors to underserviced areas.

The Liberals propose to do so by forgiving Canada Student Loans for doctors, nurses and nurse practitioners if they agree to toil in a "designated underserved small-town or rural community." Family doctors would be eligible for loan forgiveness of up to $\$ 8000$ per year to a maximum $\$ 40000$, while nurses and nurse practitioners will be eligible for forgiveness up to
$\$ 4000$ per year to a maximum $\$ 20000$. Some form of equivalent would be negotiated for Quebec students, who do not participate in the federal loans program. As well, the Liberals say they would spend $\$ 40$ million on unspecified measures to "improve rural health services" after discussing the matter with the provinces and territories.

The Conservative Party, meanwhile, declined to participate in the CMAJ survey. But it did indicate in the recent federal budget, which was not approved by Parliament (www.budget.gc.ca/2011 /plan/Budget2011-eng.pdf), that they plan to attract doctors, nurses and nurse practitioners to "under-served" rural and remote communities by forgiving students a portion of their Canada Student Loans if they agree to work in isolated environments, commencing in fiscal 2012-13. The Conservatives did not define what constitutes such communities while proposing that graduating medical students be eligible to have $\$ 8000$ per year written off their loans, to a maximum $\$ 40000$, and that nurses and nurse practitioners be eligible for a 
$\$ 4000$ per year write-off, to a maximum $\$ 20000$, if they undertake a stint in a remote community.

The Bloc Québécois asserted that Quebec is not accountable to the federal government; that the province has already established its own strategies for health human resources; and that the role of the federal government is to continue correcting the so-called fiscal imbalance by transferring more money to the provinces. - Wayne Kondro, CMAJ

Survey question: What specific measures should Canada take to resolve the shortage of physicians and other health professionals, and ensure more equitable distribution of health human resources across the country?

Conservative response:

No response. Rather than participate in CMAJ's 2011 election survey, the Conservatives forwarded a weblink to their party platform. Asked what the rationale was for declining participation, party spokesperson Ryan Sparrow says the weblink constitutes a response to the survey. "That response is the response from the campaign."

\section{Liberal response:}

"For many years, Canadians living in small towns and rural communities have expressed deep concern about the availability of health care services in their communities. While some 20 percent of Canadians live in rural areas, only 10 percent of doctors practice there. Many rural families have to travel hours to get a family doctor for their children, find mental health services, or put elderly parents in care facilities.

In cooperation with provinces and territories, a Liberal government will introduce a new incentive by forgiving a portion of Canada Student Loans for doctors, nurses and nurse practitioners choosing to practice in a designated underserved small-town or rural community. Family doctors will be eligible for student loan forgiveness up to $\$ 8,000$ per year to a maximum of $\$ 40,000$. Nurses and nurse practitioners will be eligible for student loan forgive- ness up to $\$ 4,000$ per year to a maximum of $\$ 20,000$. Quebec does not participate in the Canada Student Loans Program; therefore a Liberal government will work with the government of Quebec to determine the best ways to meet the objectives.

A Liberal government will invest an additional \$40 million over two years to improve rural health services in cooperation with provinces, territories, municipalities and medical professionals."

\section{New Democrat response:}

"Jack Layton has a comprehensive plan to address the shortage of physicians and other health professionals. New Democrats will work with the provinces and territories to address the shortage of doctors, nurses and other health care professionals by training 1,200 new doctors over the next 10 years, adding 6,000 new training spaces for nurses over six years and substantially increasing the number of training spaces for other health professionals. We will make an $\$ 80$ million contribution, over four years, to the educational infrastructure needed to create the training spaces; this will be consistent with provincial and territorial priorities.

Further, in collaboration with the provinces and territories, New Democrats will establish programs aimed at recruiting and supporting low-income, rural and aboriginal medical students. To immediately add more physicians to the health care system New Democrats will adopt the CMA's call for a fund to repatriate Canadian doctors practicing abroad to bring back 300 physicians over 4 years. We will forgive student loans for health care professionals who stay in family practice for ten years. By working with professional bodies and provincial accreditation offices we will work to streamline the credential recognition process throughout the country to get foreign trained physicians working in our system. We'll move quickly to establish reciprocity agreements so immigrants who arrive in Canada are ready to work immediately. As part of our overall strategy we'll establish a Health Human Resources Centre, often referred to as an Observatory, to identify the need for health human resources across the country and help plan for the future."

Bloc Québécois response:

"L'entente de 2004 sur la santé reconnaissait, qu'en matière de soins de santé, c'est le gouvernement québécois qui a pleine juridiction et le Québec a une obligation non pas de rendre des comptes à Ottawa mais aux Québécoises et Québécois. Bref, il revient au Québec d'établir ses propres stratégies en matière des ressources humaines afin, entre autres, de réduire les délais d'attente et de voir à la pénurie de la main d'œuvre qualifiée en santé.

De façon générale, la santé et les services sociaux sont des domaines de compétence qui relèvent exclusivement du Québec et des provinces et à ce titre, le Bloc Québécois juge que le Québec et les provinces sont les mieux à même de mettre sur pied des systèmes de soins de santé qui répondent adéquatement aux besoins de leur population respective selon les modalités qu'ils déterminent et ce, sans conditions de la part du gouvernement fédéral.

Le Bloc Québécois juge que seule la correction complète du déséquilibre fiscal qui sévit au Canada et qui prive le Québec et les provinces des revenus nécessaires pour remplir leurs responsabilités en santé et pour les services sociaux, permettra au Québec et aux provinces de développer davantage les services à leur population dans leurs champs de compétences exclusifs, avec les partenaires présents sur leur territoire et de s'assurer qu'en matière de santé et de services sociaux, leurs citoyennes."

\section{CMAJ 2011. DOI:10.1503/cmaj.109-3875}

Editor's note: Third of a series of stories on CMAJ's 2011 election survey:

Part 1: Health transfers

(www.cmaj.ca/cgi/doi/10.1503/cmaj .109-3865)

Part 2: Pharmacare

(www.cmaj.ca/cgi/doi/10.1503/cmaj .109-3870) 